\title{
A Di-Substituted Boron Dication and Its Hydride-Induced Transformation to an NHC-Stabilized Borabenzene**
}

\author{
Chao-Tang Shen, Yi-Hung Liu, Shie-Ming Peng, and Ching-Wen Chiu*
}

The intrinsic electron deficiency of borane derivatives stems from the presence of a low-lying empty $\mathrm{p}$ orbital on the boron atom. Methods to further increase the Lewis acidity of boranes include the incorporation of a boron atom into an anti-aromatic system ${ }^{[1]}$ and the introduction of electronwithdrawing groups, such as halogens, ${ }^{[2]}$ Lewis acidic elements, ${ }^{[3]}$ and cationic functionalities. ${ }^{[4]}$ Compared with the cationic boranes, for which the formal positive charges are located on the peripheral functionalities, boron cations are markedly more electron deficient and have been identified as the active intermediates in various organic transformations. ${ }^{[5]}$ Boron monocations can be classified into three categories, dicoordinated borinium, tri-coordinated borenium, and tetracoordinated boronium ions (Scheme 1$){ }^{[6]}$ The electron deficiency of the boron atom decreases as its coordination number increases.

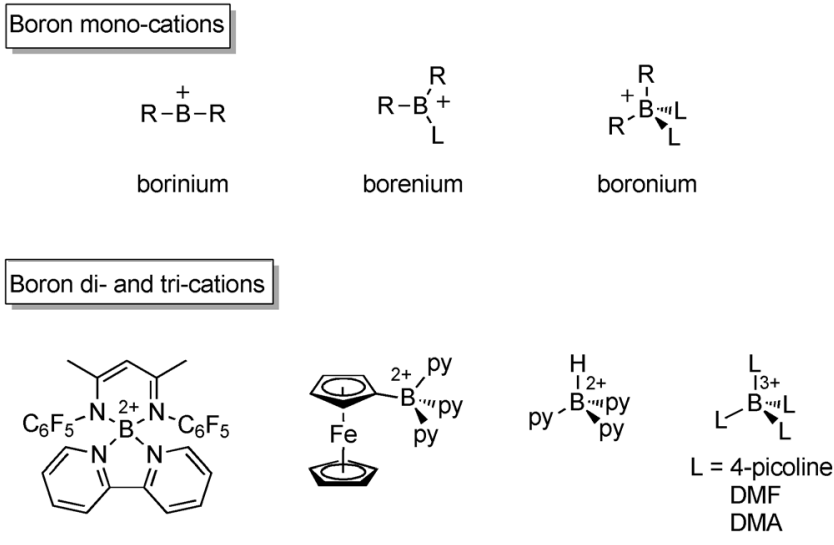

Scheme 1. Boron cations

By replacing the $\mathrm{R}$ substituents of the boronium cation with additional neutral ligands, the number of positive charges on the boron atom could exceed one. ${ }^{[7]}$ Several tetra-coordinated boron dications and trications have been structurally characterized. ${ }^{[8]}$ However, the dication version of

[*] C.-T. Shen, Y.-H. Liu, Prof. S.-M. Peng, Prof. C.-W. Chiu Department of Chemistry, National Taiwan University No.1, Sec. 4, Roosevelt Rd., Taipei, 10617 (Taiwan) E-mail: cwchiu@ntu.edu.tw

[**] This study was supported by the National Science Council of Taiwan (NSC 99-2113-M-002-011-MY2 and NSC 101-2113-M-002-013MY2). C.-W.C. extends gratitude to the Kenda Foundation for the Golden-Jade Fellowship. NHC $=\mathrm{N}$-heterocyclic carbene.

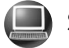
Supporting information for this article is available on the WWWW under http://dx.doi.org/10.1002/anie.201308385. the borinium ion has never been reported. With two empty p orbitals on the boron atom, stable borinium ions are rare because of the difficulty in avoiding interaction of borinium with its surroundings. The accumulation of an additional positive charge on the di-coordinated boron species further complicates its synthesis and isolation.

In recent years, the Arduengo's carbene has found numerous applications of organometallic and organic catalytic reactions, and it has played a critical role in realizing unusual boron derivatives. Those $\mathrm{N}$-heterocyclic carbene (NHC)-containing boron species include neutral diborene and diboryne ${ }^{[9]}$ boryl anions, ${ }^{[10]}$ neutral borabenzene and boraanthracene, ${ }^{[11]}$ borane radicals, ${ }^{[12]}$ and dialkylborenium and dihydroborenium cations. ${ }^{[13]}$ The strong $\sigma$-donating ability of the NHC ligand should help to stabilize the boron dication. To further stabilize the electronically and coordinatively unsaturated $\mathrm{B}^{2+}$ center, we used pentamethylcyclopentadienyl ( $\left.\mathrm{Cp}^{*}\right)$ as the $\mathrm{R}$ substituent for its potential to hypercoordinate with the boron atom. The $\mathrm{Cp}$ (cyclopentadienyl) anion is one of the most versatile ligands applied to transition-metal complexes because of its strong bonding interaction and flexible coordination arrangements with metal centers. When treated with main-group metals (E), the structural diversities of the complexes are more pronounced due to the variation in covalency of the $\mathrm{Cp}-\mathrm{E}$ bonds. ${ }^{[14]}$ Such flexible coordination of the Cp group has been used to stabilize novel boron species, including borylenes, ${ }^{[15]}$ borocenium, ${ }^{[16]}$ and $\left[\eta^{5}-\mathrm{Cp} * \mathrm{BR}\right]^{+}$cations. ${ }^{[17]}$ Herein, we demonstrate that by combining the $\mathrm{Cp}^{*}$ substituent with the bulky NHC ligand, a di-substituted boron dication can be prepared.

The synthesis of the di-substituted boron dication is depicted in Scheme 2. Addition of excess TMS-OTf into the colorless chloroform solution of the $\left[\mathrm{Cp}^{*} \mathrm{BCl}_{2}\right.$ (IMes)] adduct resulted in the formation of a light orange solution that contains the $[\mathrm{Cp} * \mathrm{~B}(\mathrm{Cl})(\mathrm{IMes})]$ borenium ion (1-OTf). The tri-coordinate geometry of the boron atom in solution was confirmed with the detection of a broad signal at $\delta=46 \mathrm{ppm}$ in the ${ }^{11} \mathrm{~B}$ NMR spectrum. The observed ${ }^{11} \mathrm{~B}$ resonance value for $\mathbf{1}^{+}$was shifted downfield compared with that reported for the similar $[\mathrm{Cp} * \mathrm{BCl}(\mathrm{L})]^{+}$borenium ions containing acridine $(\delta=32.8 \mathrm{ppm})$ or phenanthridine $(\delta=30.9 \mathrm{ppm})$ as the ligand. ${ }^{[18]}$ Geometry optimization of the putative borenium ion $\mathbf{1}^{+}$using DFT methods suggested that the $\mathrm{B}-\mathrm{Cl}$ bond is relatively weak as indicated by the $\mathrm{B}-\mathrm{Cl}$ bond length of $1.83 \AA$, which is considerably longer than the typical $\mathrm{B}\left(\mathrm{sp}^{2}\right)-$ $\mathrm{Cl}$ bonds $(1.75 \AA) \cdot{ }^{[19]}$ However, single crystal X-ray diffraction analysis of 1-OTf revealed that $\mathbf{1}^{+}$crystallizes as a contact ion pair with the triflate anion in the solid state to form a tetrahedral boron center with an averaged $\mathrm{B}-\mathrm{O}$ bond distance of $1.559 \AA$ (Figure 1). 


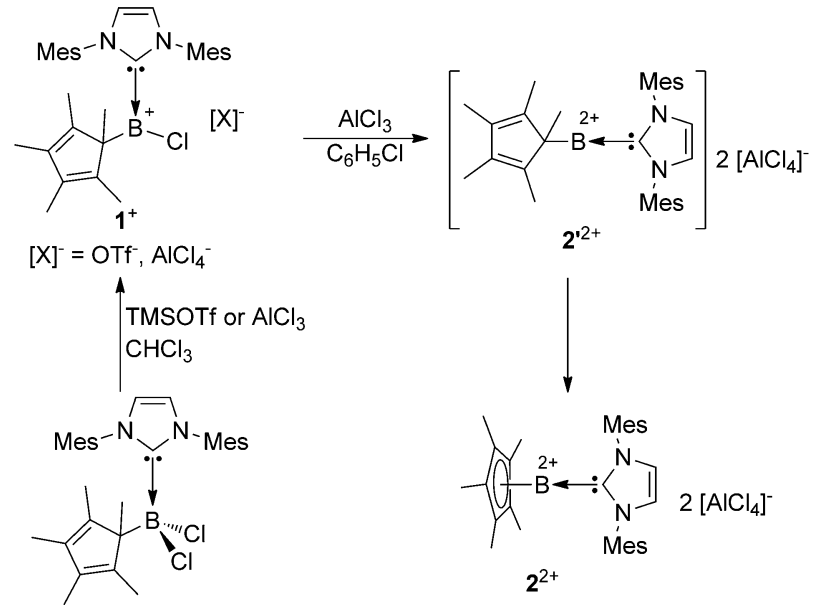

Scheme 2. Synthesis of compound $\mathbf{1}^{+}$and $\mathbf{2}^{2+}$.

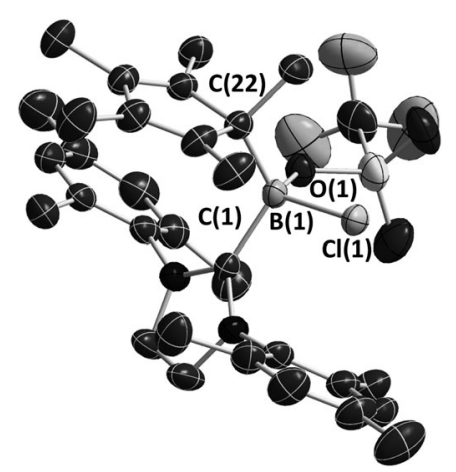

Figure 1. The molecular structure of one of the independent molecules of 1-OTf with hydrogen atoms omitted for clarity. The thermal ellipsoids are set at $50 \%$ probability. Selected bond lengths $[\AA]$ and angles $\left[^{\circ}\right]: \mathrm{B}(1)-\mathrm{Cl}(1) 1.879(3), \mathrm{B}(1)-\mathrm{O}(1) 1.561(4), \mathrm{B}(1)-\mathrm{C}(1)$ $1.668(4), B(1)-C(22) 1.641(4) ; O(1)-B(1)-C(22) 106.7(2), O(1)-B(1)-$ $\mathrm{C}(1) 105.5(2), \mathrm{C}(22)-\mathrm{B}(1)-\mathrm{C}(1) 120.1(2), \mathrm{O}(1)-\mathrm{B}(1)-\mathrm{Cl}(1)$ 107.25(18), $\mathrm{C}(22)-\mathrm{B}(1)-\mathrm{Cl}(1) 109.23(19), \mathrm{C}(1)-\mathrm{B}(1)-\mathrm{Cl}(1) 107.37(18)$.

Unfortunately, no further reaction between 1-OTf and TMS-OTf was observed at an elevated temperature with prolonged reaction times. This result suggests that a stronger halide abstractor is required. We found that $\left[\mathrm{Cp} * \mathrm{BCl}_{2}\right.$ (IMes)] could be effectively converted into another boron-containing species with two equivalents of $\mathrm{AlCl}_{3}$ in chlorobenzene. The newly isolated compound features a sharp ${ }^{11} \mathrm{~B}$ NMR signal at $\delta=-49 \mathrm{ppm}$, which is a characteristic chemical shift for a $\eta^{5}-$ $\mathrm{Cp}-\mathrm{B}$ moiety. ${ }^{[15-17]}$ Detection of the highly shielded ${ }^{11} \mathrm{~B}$ NMR signal suggested the formation of the anticipated di-substituted boron dication $\mathbf{2}^{2+}$. The ${ }^{1} \mathrm{H}$ NMR spectrum of $\mathbf{2}^{2+}$ showed that all of the methyl protons of $\mathrm{Cp}^{*}$ appeared as a sharp singlet at $\delta=1.96 \mathrm{ppm}$, implying the presence of a symmetric $\left[\mathrm{Cp}^{*} \mathrm{~B}\right]^{2+}$ unit in solution. The molecular structure of the di-substituted boron dication was confirmed with single-crystal X-ray diffraction analysis of $\mathbf{2}$-[ $\left[\mathrm{AlCl}_{4}\right]_{2}$. Single crystals of $\mathbf{2}$-[ $\left.\mathrm{AlCl}_{4}\right]_{2}$ were obtained by slow evaporation of a nitromethane solution of $\mathbf{2}-\left[\mathrm{AlCl}_{4}\right]_{2}$ under inert atmosphere. As shown in Figure 2, the boron atom was

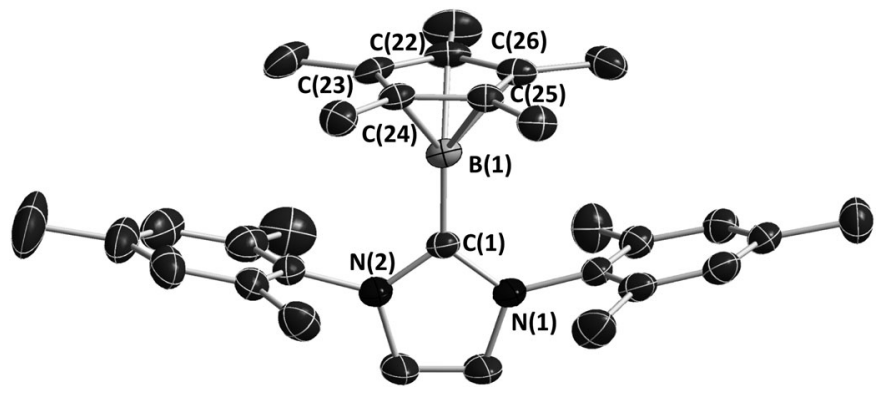

Figure 2. The molecular structure of $\mathbf{2}^{2+}$ with counteranions and hydrogen atoms omitted for clarity. The thermal ellipsoids are set at $50 \%$ probability. Selected bond lengths $[\AA]$ and angles $\left[{ }^{\circ}\right]$ : $B(1)-C(1)$ $1.558(4), B(1)-C(22) 1.751(4), B(1)-C(23) 1.752(4), B(1)-C(24)$ $1.765(4), B(1)-C(25) 1.761(4), B(1)-C(26) 1.765(4) ; C(1)-B(1)-C(22)$ $135.5(2), C(1)-B(1)-C(23) 135.4(2), C(1)-B(1)-C(24) 136.7(2), C(1)-$ $\mathrm{B}(1)-\mathrm{C}(25) 137.2(2), \mathrm{C}(1)-\mathrm{B}(1)-\mathrm{C}(26) 136.4(2), \mathrm{N}(1)-\mathrm{C}(1)-\mathrm{N}(2)$ $105.7(2)$.

located right above the centroid of the $\mathrm{Cp}^{*}$ ring with an average $\mathrm{B}-\mathrm{C}$ bond length of $1.759 \AA$. The observed $\mathrm{B}-\mathrm{C}$ bond is longer than that reported for $[\mathrm{Cp} * \mathrm{BBr}]^{+}$nidocarborane (av. $1.683 \AA$ ) as a result of steric repulsion between the $\mathrm{Cp}^{*}$ and the axial ligand IMes. ${ }^{[20]}$ The boron-ylidene bond of $1.558(4) \AA$ is typical for a $\mathrm{B}-\mathrm{C}$ single bond. The angle between the carbene-boron-Cp*(centroid) of $179.13^{\circ}$ confirms the linear geometry of the boron center. All of the structural parameters are consistent with the di-substituted boron dication description of compound $\mathbf{2}^{2+}$.

Formation of $\mathbf{2}^{2+}$ via the tri-coordinated chloroborenium $\mathbf{1}^{+}$intermediate was verified by multinuclear NMR spectroscopy. When equimolar amount of $\left[\mathrm{Cp}^{*} \mathrm{BCl}_{2}\right]$ and $\mathrm{AlCl}_{3}$ were mixed in $\mathrm{CDCl}_{3}$, the characteristic ${ }^{11} \mathrm{~B} \mathrm{NMR}$ resonance of borenium was detected. However, the resulting $\mathbf{1}-\mathrm{AlCl}_{4}$ species was not as stable as the 1-OTf, and underwent slow decomposition in solution to form the $\mathrm{BCl}_{3}-\mathrm{IMes}$ adduct and other undetermined products. With the detection of $\mathbf{1}-\mathrm{AlCl}_{4}$, we proposed a stepwise chloride abstraction mechanism for the formation of $\mathbf{2}-\left[\mathrm{AlCl}_{4}\right]_{2}$. When treated with a chloride abstractor, such as $\mathrm{AlCl}_{3},\left[\mathrm{Cp} * \mathrm{BCl}_{2}\right.$ (IMes)] lost the first chloride to form the $\left[\eta^{1}-\mathrm{Cp} * \mathrm{BCl}(\mathrm{IMes})\right]^{+}$borenium cation in solution. The subsequent second chloride abstraction resulted in the formation of the extremely electron-deficient $\sigma$ complex of the di-coordinated boron dication $\left(\mathbf{2}^{2+}\right.$; Scheme 2), which was then stabilized intramolecularly by the $\pi$-cloud of the remaining butadiene moiety to form the more stable $\pi$-complex $\mathbf{2}^{2+}$ (Scheme 2).

To obtain further insight into the electronic stabilization provided by $\mathrm{Cp}^{*}$ to the boron atom, a theoretical computation of the NHC-free boron dication, $[\mathrm{Cp} * \mathrm{~B}]^{2+}\left(\mathbf{3}^{2+}\right)$, was performed using the DFT method with a $6-311+\mathrm{G}$ basis set. The bond lengths and angles within the $[\mathrm{Cp} * \mathrm{~B}]^{2+}$ unit of $\mathbf{3}^{2+}$ were reminiscent to those experimentally determined for $\mathbf{2}^{2+}$. Molecular-orbital analysis of $\mathbf{3}^{2+}$ revealed that there were three bonding interactions between the boron atom and the $\mathrm{Cp}^{*}$ ring. One bonding orbital was the sigma-bonding interaction between the fully bonding $\pi$-orbital of $\mathrm{Cp}^{*}$ and the sp-hybrid orbital of boron. The other two bonding interactions were degenerate orbitals involving the filled 
bonding $\pi$-orbitals of $\mathrm{Cp} *$ and the empty $2 \mathrm{p}$ orbitals of boron. The stability of $\mathbf{3}^{2+}$ can also be rationalized based on Wade's rule for polyhedral boranes. Compound $\mathbf{3}^{2+}$ can be viewed as a dicationic pentagonal pyramidal nido-carborane having six vertices with sixteen cluster electrons, one from the $\mathrm{B}^{2+}$ atom and fifteen from the $\mathrm{C}_{5}$ fragment.

Remarkably, the reaction of $\mathbf{2}-\left[\mathrm{AlCl}_{4}\right]_{2}$ with one equivalent of superhydride $\left(\mathrm{LiHBEt}_{3}\right)$ in THF led to the formation of 1-IMes-2,3,4,5,6-pentamethyl borabenzene (4) in moderate yield (Scheme 3). When treated with superhydride, the

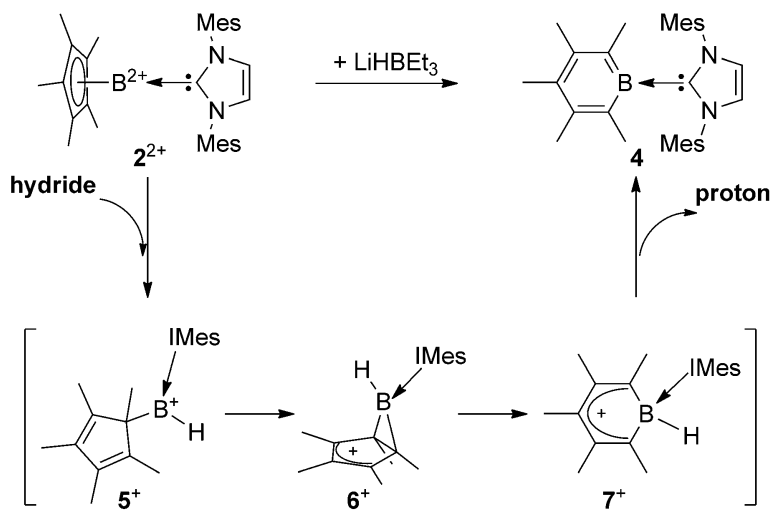

Scheme 3. Proposed mechanism for the transformation of $\mathbf{2}^{2+}$ into 4 .

solution of $\mathbf{2}$-[ $\left[\mathrm{AlCl}_{4}\right]_{2}$ gradually changed from colorless to bright yellow, and crystalline bright yellow borabenzene formed after $24 \mathrm{~h}$. The ${ }^{1} \mathrm{H}$ NMR spectroscopic characterization of 4 in $\left[D_{8}\right]$ THF revealed the presence of signals ascribed to the IMes and $\mathrm{Cp}^{*}$ moieties in a one-to-one ratio. The five equivalent methyl groups of $\mathrm{Cp}^{*}$ in $\mathbf{2}^{2+}$ split into three signals at $\delta=1.98,1.84$, and $1.68 \mathrm{ppm}$ in the spectrum of $\mathbf{4}$. The ${ }^{11} \mathrm{~B}$ resonance of 4 detected at $\delta=22.8 \mathrm{ppm}$ as a broad signal was comparable to that observed for carbene-stabilized borabenzene and boraanthracenes. ${ }^{[1]}$ The structural connectivity of 4 was further corroborated with single-crystal X-ray diffraction analysis (Figure 3). Compound 4 crystallized in the $P 21 / c$ space group as a THF solvate with four molecules in the asymmetric unit. The $\mathrm{C}_{5} \mathrm{~B}$ ring was essentially planar with similar $\mathrm{C}-\mathrm{C}$ bond distances within the $\mathrm{C}_{5} \mathrm{~B}$ ring, confirming the aromatic character of the borabenzene ring. The boronylidene bond of 1.607(4) $\AA$ was slightly elongated compared with that observed in $\mathbf{2}^{2+}$, a result of the steric congestion around the boron atom.

The synthesis of borabenzene derivatives generally relies on the elimination of $\mathrm{HCl}$ or $\mathrm{Me}_{3} \mathrm{SiCl}$ from the corresponding boracyclohexadiene molecules. ${ }^{[21]}$ The observed borabenzene formation by insertion of a boron atom into the $\mathrm{Cp}$ ring was an intriguing finding. Similar $\mathrm{Cp}$ ring-expansion reactions have been found in the reversible boron-atom insertion of metallocenes and the rearrangement of the $\mathrm{Cp}^{*}$-substituted carbenium ion. ${ }^{[22]}$ During the ring-expansion process of the $\mathrm{Cp}^{*}$-substituted carbenium ion, the molecule rearranged to produce the bicyclo[3,1,0]hexenyl cation, which could further rearrange to the benzenonium cation, the protonated benzene derivative. Since carbenium is isoelectronic to borenium, we

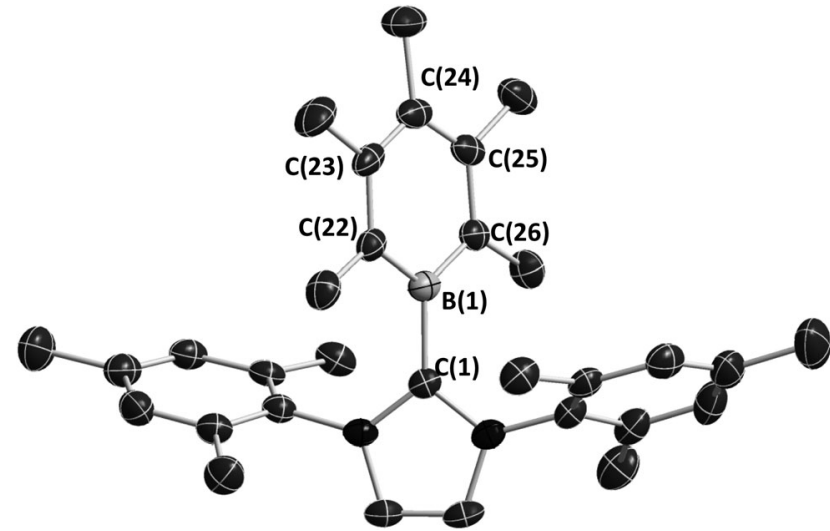

Figure 3. The molecular structure of $\mathbf{4}$ with hydrogen atoms omitted for clarity. The thermal ellipsoids are set at $50 \%$ probability. Selected bond lengths $[\AA]$ and angles $\left[{ }^{\circ}\right]: B(1)-C(1) 1.607(4), B(1)-C(22)$ $1.501(5), B(1)-C(26) 1.496(5), C(22)-C(23) 1.408(4), C(23)-C(24)$ $1.408(5), C(24)-C(25) 1.411(5), C(25)-C(26) 1.411(4) ; C(1)-B(1)-C(22)$ $119.5(3), C(1)-B(1)-C(26) 121.6(3), C(22)-B(1)-C(26) 118.9(3), B(1)-$ $C(22)-C(23) 118.1(3), C(22)-C(23)-C(24) 121.5(3), C(23)-C(24)-C(25)$ $121.7(3), C(24)-C(25)-C(26) 121.5(3), C(25)-C(26)-B(1) 118.1(3)$.

postulate that the reaction proceeds via the hydroborenium intermediate $\left(\mathbf{5}^{+}\right)$, the hydride addition product of $\mathbf{2}^{2+}$. A proposed mechanism for the hydride-induced transformation of $\mathbf{2}^{2+}$ to $\mathbf{4}$ is depicted in Scheme 3. After hydride addition, the resulting putative hydroborenium $\mathbf{5}^{+}$quickly transforms into the bicyclo[3,1,0]borahexenyl cation $\mathbf{6}^{+}$and then to the borabenzenonium cation $\mathbf{7}^{+}$. The subsequent deprotonation of $\mathbf{7}^{+}$driven by the aromatic stabilization of the $\mathrm{C}_{5} \mathrm{~B}$ ring leads to the formation of the NHC-stabilized borabenzene (4).

In summary, a di-substituted boron dication featuring a $\eta^{5}$ coordinated $\mathrm{Cp}^{*}$ fragment and an axial IMes ligand was synthesized in a stepwise chloride abstraction of the $\left[\mathrm{Cp} * \mathrm{BCl}_{2}\right.$ (IMes)] adduct. The hypercoordinated boron dication $\mathbf{2}^{2+}$ can be viewed as the resting state of the highly electron-deficient di-coordinated $\sigma$-complex $\mathbf{2}^{\prime 2+}$. Opening the pentagonal pyramidal $\left[\mathrm{C}_{5} \mathrm{~B}\right]^{2+}$ core with superhydride led to the isolation of an NHC-stabilized borabenzene. The transformation of $\mathbf{2}^{2+}$ into $\mathbf{4}$ is proposed to proceed through the putative hydroborenium intermediate $\mathbf{5}^{+}$followed by deprotonation to produce the aromatic borabenzene derivative. Further reactivity studies of $\mathbf{2}^{2+}$ and the preparation of related Group 13 dications are currently under investigation.

\section{Experimental Section}

2-[ $\left.\mathrm{AlCl}_{4}\right]_{2}$ : IMes $(200 \mathrm{mg}, 0.657 \mathrm{mmol})$ was added to a solution of [Cp*BCl $\mathrm{C}_{2}$ (190 mg, $\left.0.865 \mathrm{mmol}\right)$ in hexane $(10 \mathrm{~mL})$ and stirred for $4 \mathrm{~h}$ to yield [Cp* $\mathrm{BCl}_{2}$ (IMes)] as a white precipitate. After washing with hexane, $\left[\mathrm{Cp} * \mathrm{BCl}_{2}\right.$ (IMes)] adduct was allowed to react with $\mathrm{AlCl}_{3}$ granules $(180 \mathrm{mg}, 1.35 \mathrm{mmol})$ in $\mathrm{C}_{6} \mathrm{H}_{5} \mathrm{Cl}(15 \mathrm{~mL})$ for $24 \mathrm{~h}$. The solution turned from colorless to orange, and then to yellow. After the reaction, the precipitate was collected and washed with ether to yield 2-[ $\left[\mathrm{AlCl}_{4}\right]_{2}$ as a white solid $(560 \mathrm{mg}$ ). Yield: $71 \%$ (calculated based on the IMes). ${ }^{1} \mathrm{H}$ NMR $\left(400.2 \mathrm{MHz}, \mathrm{CD}_{3} \mathrm{NO}_{2}, 299.9 \mathrm{~K}\right): \delta=7.94(\mathrm{~s}, 2 \mathrm{H}$, $\mathrm{NCH}$ ), 7.40 (s, $4 \mathrm{H}, \mathrm{Mes}), 2.49$ (s, 6H, $p$-Me, Mes), 2.17 (s, $12 \mathrm{H}, o-\mathrm{Me}$, Mes), 1.96 ppm (s, $15 \mathrm{H}, \mathrm{Me}, \mathrm{Cp} *) ;{ }^{11} \mathrm{~B}$ NMR $\left(128.4 \mathrm{MHz}, \mathrm{CD}_{3} \mathrm{NO}_{2}\right.$, $299.9 \mathrm{~K}): \delta=-49 \mathrm{ppm} ;{ }^{13} \mathrm{C} \mathrm{NMR}\left(100.6 \mathrm{MHz}, \mathrm{CD}_{3} \mathrm{NO}_{2}, 299.9 \mathrm{~K}\right)$ : 
$\delta=145.3(\mathrm{~s}, p-\mathrm{C}, \mathrm{Mes}), 136.7$ (s, ipso-C, Mes), $132.4(\mathrm{~s}, \mathrm{NCH}), 132.1$ (s, $o$-C, Mes), 132.0 (s, $m$-C, Mes), 117.5 ( $\left.\mathrm{s}^{\mathrm{C}} \mathrm{C}_{5}, \mathrm{Cp}^{*}\right), 21.4$ (s, $p$-Me, Mes), 18.1 (s, o-Me, Mes), $9.3 \mathrm{ppm}\left(\mathrm{s}, \mathrm{Me}, \mathrm{Cp}^{*}\right)$; Elemental analysis calculated (\%) for $\mathrm{C}_{31} \mathrm{H}_{39} \mathrm{Al}_{2} \mathrm{BCl}_{8} \mathrm{~N}_{2}$ : C 47.25, $\mathrm{H} 4.99, \mathrm{~N} 3.55$; found $\mathrm{C}$ 46.74, H 5.31, N 3.52

4: $\operatorname{LiHBEt}_{3}(1 \mathrm{M}$ in THF, $63 \mu \mathrm{L}, 0.0634 \mathrm{mmol})$ was slowly added into a THF solution of 2 -[ $\left[\mathrm{AlCl}_{4}\right]_{2}(50 \mathrm{mg}, 0.0634 \mathrm{mmol})$, and the resulting reaction mixture was allowed to stand at room temperature for $24 \mathrm{~h}$. After the reaction, the crystalline solid was collected and washed with $1 \mathrm{~mL}$ of cold THF to yield compound $\mathbf{4}$ as a bright yellow solid (15 mg). Yield: $16 \% .{ }^{1} \mathrm{H}$ NMR (400.2 MHz, [D 8 ]THF, $\left.299.9 \mathrm{~K}\right)$ : $\delta=7.51$ (s, 2 H, NCH), 6.83 (s, 4 H, Mes), 2.22 (s, 6 H, $p$-Me, Mes), 2.14 (s, $12 \mathrm{H}, o$-Me, Mes), 1.98 (s, 3H, $p$-Me, $\mathrm{C}_{5} \mathrm{~B}$ ), 1.84 (s, 6H, $m$-Me, $\mathrm{C}_{5} \mathrm{~B}$ ), $1.68 \mathrm{ppm}\left(\mathrm{s}, 6 \mathrm{H}, o-\mathrm{Me}, \mathrm{C}_{5} \mathrm{~B}\right) ;{ }^{11} \mathrm{~B}$ NMR $\left(128.4 \mathrm{MHz}, \mathrm{CD}_{3} \mathrm{NO}_{2}\right.$, $299.9 \mathrm{~K}): \delta=22.8 \mathrm{ppm} ;{ }^{13} \mathrm{C} \mathrm{NMR}\left(100.6 \mathrm{MHz}, \mathrm{CD}_{3} \mathrm{NO}_{2}, 299.9 \mathrm{~K}\right)$ : $\delta=170.8$ (s, IMes-C2), 138.9 (s, $p$-C, Mes), 135.3 (s, ipso-C, Mes), 135.2 (s, $\left.m-\mathrm{C}, \mathrm{C}_{5} \mathrm{~B}\right), 135.1$ (s, $\left.o-\mathrm{C}, \mathrm{Mes}\right), 130.2$ (s, $m$-C, Mes), 129.0 (s, $o$-C, $\left.\mathrm{C}_{5} \mathrm{~B}\right), 123.9(\mathrm{~s}, \mathrm{NCH}), 120.5\left(\mathrm{~s}, p-\mathrm{C}, \mathrm{C}_{5} \mathrm{~B}\right), 22.1$ (s, $\left.o-\mathrm{Me}, \mathrm{C}_{5} \mathrm{~B}\right), 20.9$ (s, $p$-Me, Mes), 19.4 (s, $o$-Me, Mes), 18.1 (s, $p$-Me, $\mathrm{C}_{5} \mathrm{~B}$ ), 17.2 ppm (s, $m$-Me, $\mathrm{C}_{5} \mathrm{~B}$ ); Elemental analysis calculated (\%) for $\mathrm{C}_{32} \mathrm{H}_{41} \mathrm{BN}_{2} \mathrm{O}_{0.25}: \mathrm{C}$ 82.04, H 8.82, N 5.98; found C 82.24, H 8.82, N 5.86.

Received: September 25, 2013

Published online: November 8, 2013

Keywords: boron · cations · heterocycles .

$\mathrm{N}$-heterocyclic carbenes

[1] a) H. Braunschweig, I. Fernández, G. Frenking, T. Kupfer, Angew. Chem. 2008, 120, 1977-1980; Angew. Chem. Int. Ed. 2008, 47, 1951-1954; b) C. Fan, W. E. Piers, M. Parvez, Angew. Chem. 2009, 121, 2999-3002; Angew. Chem. Int. Ed. 2009, 48, $2955-2958$; c) C. Fan, L. G. Mercier, W. E. Piers, H. M. Tuononen, M. Parvez, J. Am. Chem. Soc. 2010, 132, 9604-9606; d) H. Braunschweig, T. Kupfer, Chem. Commun. 2011, 47, $10903-$ 10914; e) A. Fukazawa, J. L. Dutton, C. Fan, L. G. Mercier, A. Y. Houghton, Q. Wu, W. E. Piers, M. Parvez, Chem. Sci. 2012, 3, 1814-1818.

[2] a) W. E. Piers, T. Chivers, Chem. Soc. Rev. 1997, 26, 345-354; b) W. E. Piers, Adv. Organomet. Chem. 2004, 52, 1-76; c) G. Erker, Dalton Trans. 2005, 1883-1890; d) S. A. Cummings, M. Iimura, C. J. Harlan, R. J. Kwaan, I. V. Trieu, J. R. Norton, B. M Bridgewater, F. Jakle, A. Sundararaman, M. Tilset, Organometallics 2006, 25, $1565-1568$; e) A. E. Ashley, T. J. Herrington, G. G. Wildgoose, H. Zaher, A. L. Thompson, N. H. Rees, T. Krämer, D. O'Hare, J. Am. Chem. Soc. 2011, 133, 14727-14740; f) H. Zhao, J. H. Reibenspies, F. P. Gabbaï, Dalton Trans. 2013, $42,608-610$.

[3] a) W. Kaim, A. Schulz, Angew. Chem. 1984, 96, 611-612; Angew. Chem. Int. Ed. Engl. 1984, 23, 615-616; b) M. Melaïmi, S. Solé, C.-W. Chiu, H. Wang, F. P. Gabbaï, Inorg. Chem. 2006, 45, 8136-8143; c) M. Melaimi, F. P. Gabbaï, Adv. Organomet. Chem. 2005, 53, 61-99.

[4] a) T. W. Hudnall, C.-W. Chiu, F. P. Gabbaï, Acc. Chem. Res. 2009, 42, 388 - 397; b) C.-W. Chiu, Y. Kim, F. P. Gabbaï, J. Am. Chem. Soc. 2009, 131, 60-61.

[5] a) A. Prokofjevs, J. W. Kampf, E. Vedejs, Angew. Chem. 2011, 123, 2146-2149; Angew. Chem. Int. Ed. 2011, 50, 2098-2101; b) A. Del Grosso, P. J. Singleton, C. A. Muryn, M. J. Ingleson, Angew. Chem. 2011, 123, 2150-2154; Angew. Chem. Int. Ed. 2011, 50, 2102-2106; c) A. Del Grosso, M. D. Helm, S. A Solomon, D. Caras-Quintero, M. J. Ingleson, Chem. Commun. 2011, 47, 12459-12461; d) A. Prokofjevs, A. Boussonnière, L. Li, H. Bonin, E. Lacôte, D. P. Curran, E. Vedejs, J. Am. Chem. Soc. 2012, 134, 12281-12288; e) J. M. Farrell, J. A. Hatnean, D. W. Stephan, J. Am. Chem. Soc. 2012, 134, 15728-15731; f) J. R.
Lawson, E. R. Clark, I. A. Cade, S. A. Solomon, M. J. Ingleson, Angew. Chem. 2013, 125, 7666-7670; Angew. Chem. Int. Ed. 2013, 52, 7518-7522; g) V. Bagutski, A. Del Grosso, J. Ayuso Carrillo, I. A. Cade, M. D. Helm, J. R. Lawson, P. J. Singleton, S. A. Solomon, T. Marcelli, M. J. Ingleson, J. Am. Chem. Soc. 2013, 135, 474-487; h) T. Stahl, K. Müther, Y. Ohki, K. Tatsumi, M. Oestreich, J. Am. Chem. Soc. 2013, 135, 10978-10981.

[6] a) P. Koelle, H. Noeth, Chem. Rev. 1985, 85, 399-418; b) W. E. Piers, S. C. Bourke, K. D. Conroy, Angew. Chem. 2005, 117, 5142-5163; Angew. Chem. Int. Ed. 2005, 44, 5016-5036; c) T. S. De Vries, A. Prokofjevs, E. Vedejs, Chem. Rev. 2012, 112, $4246-$ 4282.

[7] a) M. A. Mathur, G. E. Ryschkewitsch, Inorg. Chem. 1980, 19, 3054-3057; b) M. J. Farquharson, J. S. Hartman, Can. J. Chem. 1996, 74, 1309-1320; c) M. A. Mathur, G. E. Ryschkewitsch, T. C. Long, J. C. Carter, Inorg. Synth. 2007, 139-141.

[8] a) A. Bekaert, O. Barberan, E. B. Kaloun, C. Rabhi, A. Danan, J. D. Brion, P. Lemoine, B. Viossat, Z. Kristallogr. New Cryst. Struct. 2002, 217, 507-509; b) A. Bekaert, O. Barberan, E. B. Kaloun, C. Rabhi, A. Danan, J. D. Brion, P. Lemoine, B. Viossat, Z. Kristallogr. New Cryst. Struct. 2003, 218, 123-124; c) D. Vidovic, M. Findlater, A. H. Cowley, J. Am. Chem. Soc. 2007, 129, 11296-11296; d) I. Vargas-Baca, M. Findlater, A. Powell, K. V. Vasudevan, A. H. Cowley, Dalton Trans. 2008, 6421-6426; e) H. Braunschweig, M. Kaupp, C. Lambert, D. Nowak, K. Radacki, S. Schinzel, K. Uttinger, Inorg. Chem. 2008, 47, $7456-$ 7458.

[9] a) Y. Wang, B. Quillian, P. Wei, C. S. Wannere, Y. Xie, R. B. King, H. F. Schaefer III, P. v. R. Schleyer, G. H. Robinson, $J$. Am. Chem. Soc. 2007, 129, 12412-12413; b) Y. Wang, B. Quillian, P. Wei, Y. Xie, C. S. Wannere, R. B. King, H. F. Schaefer III, P. v. R. Schleyer, G. H. Robinson, J. Am. Chem. Soc. 2008, 130, 3298-3299; c) H. Braunschweig, R. D. Dewhurst, K. Hammond, J. Mies, K. Radacki, A. Vargas, Science 2012, 336, $1420-1422$

[10] a) H. Braunschweig, C.-W. Chiu, K. Radacki, T. Kupfer, Angew. Chem. 2010, 122, 2085-2088; Angew. Chem. Int. Ed. 2010, 49 , 2041-2044; b) J. Monot, A. Solovyev, H. Bonin-Dubarle, É. Derat, D. P. Curran, M. Robert, L. Fensterbank, M. Malacria, E. Lacôte, Angew. Chem. 2010, 122, 9352-9355; Angew. Chem. Int. Ed. 2010, 49, 9166-9169.

[11] a) X. Zheng, G. E. Herberich, Organometallics 2000, 19, 3751 3753 ; b) T. K. Wood, W. E. Piers, B. A. Keay, M. Parvez, Angew. Chem. 2009, 121, 4069-4072; Angew. Chem. Int. Ed. 2009, 48, 4009-4012.

[12] a) S.-H. Ueng, M. Makhlouf Brahmi, É. Derat, L. Fensterbank, E. Lacôte, M. Malacria, D. P. Curran, J. Am. Chem. Soc. 2008, 130, 10082-10083; b) T. Matsumoto, F. P. Gabbaï, Organometallics 2009, 28, 4252-4253; c) J. C. Walton, M. M. Brahmi, J. Monot, L. Fensterbank, M. Malacria, D. P. Curran, E. Lacôte, J. Am. Chem. Soc. 2011, 133, 10312-10321; d) X. Pan, E. Lacôte, J. Lalevée, D. P. Curran, J. Am. Chem. Soc. 2012, 134, 5669-5674.

[13] a) D. McArthur, C. P. Butts, D. M. Lindsay, Chem. Commun. 2011, 47, 6650-6652; b) A. Solovyev, S. J. Geib, E. Lacôte, D. P. Curran, Organometallics 2011, 30, 54-56.

[14] a) P. Jutzi, N. Burford, Chem. Rev. 1999, 99, 969-990; b) P. H. M. Budzelaar, J. J. Engelberts, J. H. van Lenthe, Organometallics 2003, 22, 1562-1576.

[15] a) A. H. Cowley, V. Lomeli, A. Voigt, J. Am. Chem. Soc. 1998, 120, 6401-6402; b) C. L. B. Macdonald, A. H. Cowley, J. Am. Chem. Soc. 1999, 121, 12113-12126; c) P. Greiwe, A. Bethauser, H. Pritzkow, T. Kuhler, P. Jutzi, W. Siebert, Eur. J. Inorg. Chem. 2000, 1927 -1929; d) D. Vidovic, M. Findlater, G. Reeske, A. H. Cowley, Chem. Commun. 2006, 3786-3787.

[16] a) P. Jutzi, A. Seufert, J. Organomet. Chem. 1978, 161, C5-C7; b) A. Voigt, S. Filipponi, C. L. B. Macdonald, J. D. Gorden, A. H. Cowley, Chem. Commun. 2000, 911-912; c) O. Kwon, 
M. L. McKee, J. Phys. Chem. A 2001, 105, 10133-10138; d) C. L. B. Macdonald, J. D. Gorden, A. Voigt, S. Filipponi, A. H. Cowley, Dalton Trans. 2008, $1161-1176$.

[17] a) P. Jutzi, A. Seufert, Angew. Chem. 1977, 89, 339-340; Angew. Chem. Int. Ed. Engl. 1977, 16, 330-331; b) P. Jutzi, A. Seufert, W. Buchner, Chem. Ber. 1979, 112, 2488-2493; c) U. Holtmann, P. Jutzi, T. Kuehler, B. Neumann, H.-G. Stammler, Organometallics 1999, 18, 5531-5538.

[18] P. Jutzi, B. Krato, M. Hursthouse, A. J. Howes, Chem. Ber. 1987, 120, $1091-1098$.

[19] a) H. Braunschweig, C.-W. Chiu, J. Wahler, K. Radacki, T. Kupfer, Chem. Eur. J. 2010, 16, 12229-12233; b) Y. Wang, G. H. Robinson, Inorg. Chem. 2011, 50, 12326-12337.

[20] C. Dohmeier, R. Koeppe, C. Robl, H. Schnoeckel, J. Organomet. Chem. 1995, 487, 127-130.
[21] a) G. E. Herberich, H. Ohst, Adv. Organomet. Chem. 1986, 25, 199-236; b) G. C. Fu, Adv. Organomet. Chem. 2001, 47, $101-$ 119.

[22] a) G. E. Herberich, G. Greiss, H. F. Heil, Angew. Chem. 1970, 82 , 838-839; Angew. Chem. Int. Ed. Engl. 1970, 9, 805-806; b) G. E. Herberich, G. Greiss, Chem. Ber. 1972, 105, 3413-3423; c) U. Hagenau, J. Heck, E. Hendrickx, A. Persoons, T. Schuld, H. Wong, Inorg. Chem. 1996, 35, 7863-7866; d) S. Winstein, M. Battiste, J. Am. Chem. Soc. 1960, 82, 5244-5245; e) R. F. Childs, M. Sakai, B. D. Parrington, S. Winstein, J. Am. Chem. Soc. 1974, 96, 6403-6409; f) R. F. Childs, S. Winstein, J. Am. Chem. Soc. 1974, 96, 6409-6417; g) P. Jutzi, A. Mix, T. Lindermeier, H.-G. Stammler, B. Neumann, Chem. Ber. 1994, 127, 107-112. 